EESTI NSV TEADUSTE AKADEEMIA TOIMETISED. VIII KOIDE
BIOLOOGILINE SEERIA. 1959, NR. 1

ИЗВЕСТИЯ АКАДЕМИИ НАУК ЭСТОНСКОИ ССР. ТОМ VII

СЕРИЯ БИОЛОГИЧЕСКАЯ. 1959, 스 1

\title{
METSA VARE HULK JA KOOSTIS LOOMETSAS
}

\section{R. SEPP}

Seoses looalade metsastamise ja loometsade majandamisega alustati 1956. aastal ENSV TA Zooloogia ja Botaanika Instituudis uurimistöid loomuldade (paepealsed e. huumus-karbonaatmullad) metsakasvatuslike omaduste tundmaõppimiseks. Silmas pidades loomuldade viljakuse tōstmist, kuulub suur osa sellest tööst metsataimestiku ja mulla vaheliste suhete väljaselgitamisele, mis on väga mitmekülgsed. Vōib julgesti väita, et seni oleme neist ainult üksikuid tundma õppinud. Teatavat edu selles suhtes on saavutatud alles viimastel aastatel, tănu V. Sukatšovi (1947) poolt arendatud biogeotsönoloogia teooria praktilisele rakendamisele.

Biogeotsönoloogilisest seisukohast lähtudes on metsa ja mulla keeruliste suhete aluseks nende vahel pidevalt toimuv ainevahetusprotsess. Selle olulisemaid momente on puude poolt tarvitatud mineraalainete suurema osa tagastamine mulda koos sureva orgaanilise ainega - metsa varega.

Vare hulgast ja koostisest oleneb metsa ia mulla vahel toimuva ainevahetusprotsessi intensiivsus. mis omakorda mõjutab mullatekkeprotsessi kvantitatiivseid ja kvalitatiivseid külgi. Seepärast on metsa ja üksikute puuliikide osatähtsuse mőistmiseks loomuldade arengu protsessis oluline teada metsa vare hulka, langemise dünaamikat ja koostist.

Allpool ongi neid küsimusi käsitletud Kuusiku metskonna loometsadest 1956.-1957. aastani kogutud materjalide pōhjal.

\section{Uurimisobjektid ja -metoodika}

Pae sügavuse, struktuuri, lagunemise astme ja teiste metsa kasvu mõjustavate tegurite suur varieeruvus pōhjustab erinevate metsakasvatuslike omadustega puistute esinemist loometsades. Tüüpiliste puistute väljaselgitamiseks toimus 1956. a. kevadel Kuusiku, Vardi ja Märjamaa metskonna loometsade marsruut-uurimine. Saadud andmed olid aluseks üheksa statsionaarse proovitüki rajamisele Kuusiku metskonna Koikse (proovitükid nr. 1-4) ja Abru (proovitükid nr. 5-9) vahtkonnas (tabel 1).

Puistute takseeriseloomustus

Tabel 1

\begin{tabular}{|c|c|c|c|c|c|c|c|c|c|c|c|c|c|}
\hline \multirow{2}{*}{ 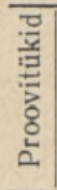 } & \multirow{2}{*}{ Koosseis } & \multirow{2}{*}{ 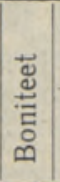 } & \multicolumn{2}{|c|}{$\begin{array}{l}\text { Vanus } \\
\text { aastates }\end{array}$} & \multirow{2}{*}{ Täius } & \multirow{2}{*}{$\begin{array}{l}\text { Kesk- } \\
\text { mine } \\
\text { kōr- } \\
\text { gus } \\
\mathrm{m}\end{array}$} & \multirow{2}{*}{$\begin{array}{c}\text { Kesk- } \\
\text { mine } \\
\text { dia- } \\
\text { meeter } \\
\mathrm{cm}\end{array}$} & \multicolumn{3}{|c|}{$\begin{array}{c}\text { Puude arv } \\
\text { pro ha }\end{array}$} & \multicolumn{3}{|c|}{$\begin{array}{c}\text { Tagavara tm } \\
\text { pro ha }\end{array}$} \\
\hline & & & $\begin{array}{c}\text { Valit- } \\
\text { sev }\end{array}$ & $\begin{array}{l}\text { Kesk- } \\
\text { mine }\end{array}$ & & & & $\frac{\vec{z}}{\frac{y}{b}}$ & 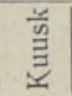 & 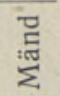 & $\begin{array}{l}\frac{\vec{y}}{y} \\
\frac{y}{0}\end{array}$ & 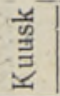 & 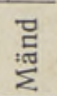 \\
\hline 1 & $9 \mathrm{Ku}^{*} 1 \mathrm{Mä**}$ & III & 77 & 75 & 0,90 & 18,4 & 20,6 & 856 & 744 & 112 & 270 & 240 & 30 \\
\hline 2 & 7 Ku $3 \mathrm{Mä}$ & III & 85 & 92 & 0 , & is & 2 & 500 & 37 & 124 & 214 & 1. & 71 \\
\hline 3 & $8 \mathrm{Ku} 2 \mathrm{Mä}$ & IV & 96 & 103 & 0,6 & 16 & 20,6 & 620 & 552 & 68 & 187 & 14 & 6 \\
\hline 4 & $5 \mathrm{Ku} 5 \mathrm{Mä}$ & III & 60 & 51 & 0 , & 14 & 1 & 1360 & 776 & 584 & 167 & $x^{2}$ & 8 \\
\hline 5 & $5 \mathrm{Ku}$ & IV & 65 & 66 & 0, & 14 & 14,5 & 1252 & 444 & 808 & 174 & 9 & 7 \\
\hline 6 & $5 \mathrm{Ku} 5$ Mä & IV & 70 & 72 & 0, & 12 & 13 & 17 & 1072 & 6 & 166 & 85 & 1 \\
\hline 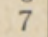 & 7 Mä & $\mathrm{V}$ & 50 & a & 0,4 & & 12,0 & 884 & 216 & & 54 & 13 & 41 \\
\hline 8 & 9 Mä $1 \mathrm{Ku}$ & V & 130 & 124 & 0,6 & 15 & 22 & 5 & 36 & 5 & 159 & 11 & 148 \\
\hline 9 & $5 \mathrm{Ku} 5 \mathrm{Mä}$ & IV & 70 & 69 & 0,74 & 15,5 & 16,6 & 1044 & 576 & 468 & 177 & 94 & 83 \\
\hline
\end{tabular}


Paepealsete muldade metsakasvatuslike omaduste iseloomustamisel, samuti erimiteks jaotamisel kasutatakse olulise näitajana peeneselise mullakihi tüsedust ehk nn. pae sügavust. Viimane määrati proovitüki mōlemal diagonaalil metallvardaga iga sammu järel (ca 100 mōõtmist) ja leiti keskmised peeneselise mullakihi tüsedused (tabel 2).

Peeneselise horisondi tüsedused proovitükkidel

Tabel 2

\begin{tabular}{c|c|c|c|c|c|c|c|c|c}
\hline Proovitükid & 1 & 2 & 3 & 4 & 5 & 6 & 7 & 8 & 9 \\
\hline $\begin{array}{c}\text { Keskmine tüsedus } \\
(\mathrm{cm})\end{array}$ & 10,2 & 12,2 & 9,2 & 13,0 & 14,7 & 8,6 & 4,4 & 4,9 & 9,4
\end{tabular}

Peeneselise mullakihi tüsedus üksinda ei iseloomusta ammendavalt paepealsete muldade metsakasvatuslikke omadusi. Sageli on olulisemaks tunnuseks alumistes horisontides paepragude vahel olev mulla peenese hulk, mis oleneb pae struktuurist, lagunemise astmest ja iseloomust.

Parimad kasvutingimused valitsevad proovitükkidel nr. 1 ja 4 , sest paas on siin $30 \mathrm{~cm}$ sügavuses tugevasti lagunenud, nii et mustjaspruuni värvusega struktuurse mulla ja pae vahekord on 1:1.

Proovitükkidel $\mathrm{nr} .2$ ja 3 on paas $30 \mathrm{~cm}$ sügavuses märgatavalt vähem lagunenud; peeneseks on pruunikaskollane savi, mille suhe paesse on 1:10. Vähelagunenud (massiivne) paas algab 50-60 cm sügavuselt (foto 1), kuid üksikud puude juured tungivad mööda lõhesid kuni $70-80 \mathrm{~cm}$ sügavuseni.

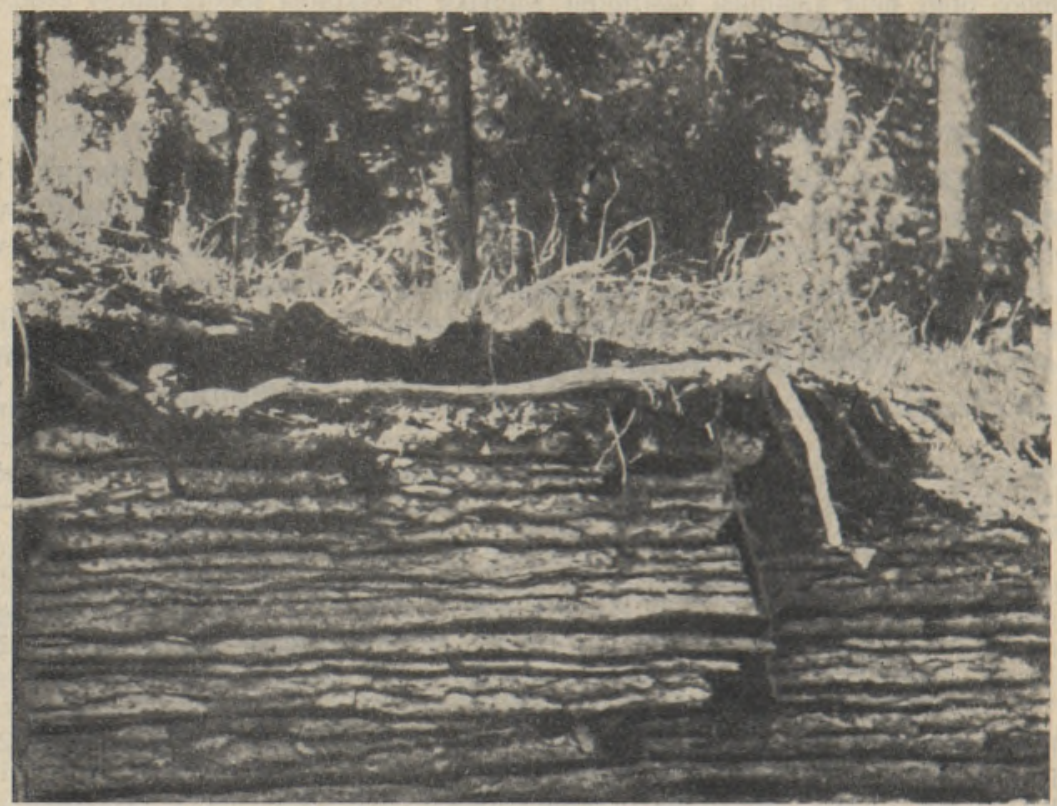

Foto 1. Huumus-karbonaatmulla profiil proovitükil nr. 3 .

Puistute kasvutingimustes proovitükkidel nr. 2 ja 3 olulisi erinevusi ei esine. Nad valiti katsealadeks vaid selleks, et kontrollida kasutatavaid meetodeid.

Abru vahtkonnas on parimad kasvutingimused proovitükil nr. 5. Peeneselise horisondi tüsedus on siin $\mathrm{ca} 15 \mathrm{~cm}$; vähelagunenud paas algab 
35-40 cm sügavuselt, millest allapoole puude juured enam ei tungi. Risosfääri tüsedust kompenseerib suurem mulla niiskus, mis on tingitud madalast, lohutaolisest reljeefist. Sademete perioodidel on ala üle ujutatud ja pae vähelōhestunud struktuuri tōttu püsib vesi kaua maapinnal või mulla peeneselises horisondis.

Mullastikutingimusi proovitükil nr. 6 iseloomustab $200-600 \mathrm{~m}^{2}$ suuruste laikude esinemine, kus mulla peeneseline kiht täiesti puudub ja 2-3 m läbimõõduga $8-12 \mathrm{~cm}$ paksusi paeplaate katab ühtlane samblavaip (Pleurozium schreberi ja Hylocomium proliferum). Paeplaatide all on 2-4 cm tüsedune paemurendi ja musta, struktuurse mulla segune horisont. Sellele järgneb $3-4 \mathrm{~cm}$ tüsedune rähakiht, segatud vähese hulga savika, kollase peenesega. Järgnevad paksud paeplaadid, millest puude juured sügavamale ei tungi. Kirjeldatud laigud on kaetud tiheda $20-40$ aastase kuusenoorendikuga, mille suhteliselt hea kasv on seletatav sellega, et paeplaatide kate aitab säilitada peeneselises horisondis küllaldaselt niiskust.

Laikudevahelisel alal kasvavad vanemad männid ja kuused. Peeneselise horisondi tüsedus on siin ca $9 \mathrm{~cm}$; sellele järgneb $35 \mathrm{~cm}$ tüsedune räha-peenese kiht. Vähelagunenud paas asub $45-50 \mathrm{~cm}$ sügavusel.

Mullastikutingimused proovitükil nr. 9 sarnanevad proovitüki nr. 6 paelaikudevaheliste aladega. Samuti on palju ühist nende proovitükkide puistute ehituses ja üldilmes; erinevus on vaid noorte kuuskede suuremas arvus proovitükil nr. 6 .

Köige halvemate mullastikutingimustega on proovitükid nr. 7 ja 8 , mis asuvad suhteliselt kõrgema, kumera reljeefiga aladel. Ohukesele $(5 \mathrm{~cm})$ peeneselisele mullakihile järgneb $15-20 \mathrm{~cm}$ tüsedune vähese peenesega segatud rähahorisont. Massiivne paas algab proovitükil nr. $730-35 \mathrm{~cm}$ ja proovitükil nr. $8 \quad 40-45 \mathrm{~cm}$ sügavuselt. Peenese vähese hulga ning kõrge reljeefi tõttu on niiskusvaru mullas väike, mille tagajärjel metsa kasv kuivuse all tublisti kannatab (sageli «kõrbeb» juulis alustaiméstik). Puistud on hõredad, puude tüved suure koondega ja kõverad ning võrad ažuursed.

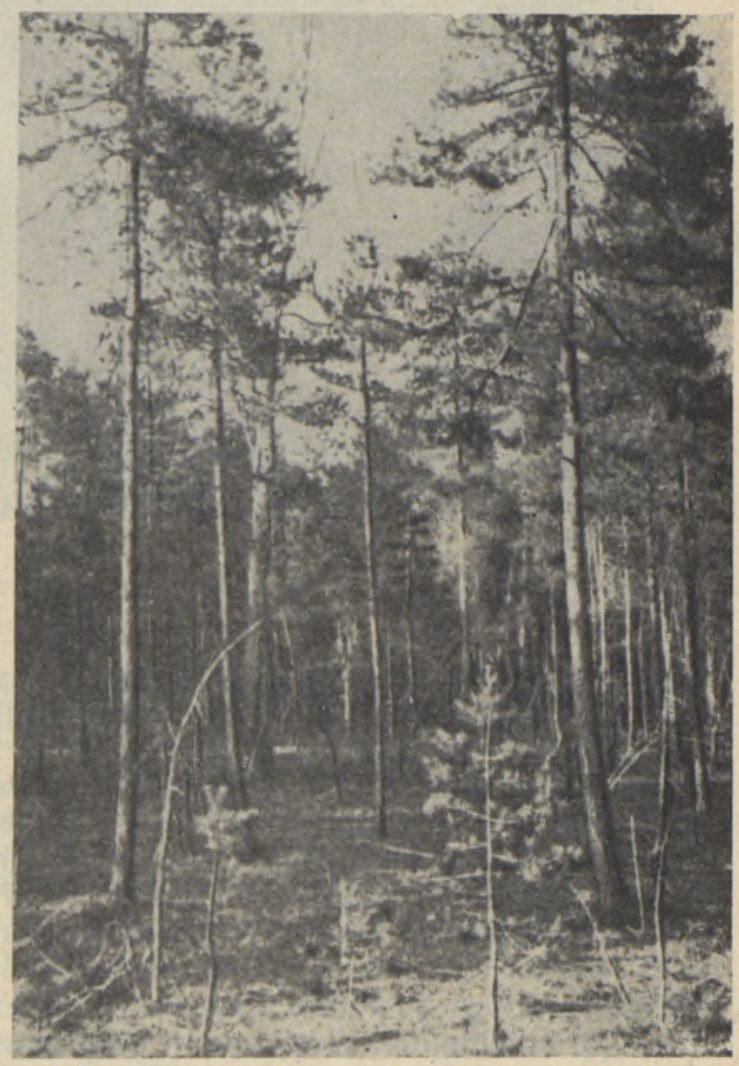

Foto 2. Puistu proovitükil nr. 7 .

Uheksa proovitükki hõlmavad ühtekokku kahte mullaerimit — väga ōhukesi ja õhukesi huumus-karbonaat- e. paepealseid muldi. Peeneselise mullakihi tüseduse kõikuvused ei ole suured ja erinevused kasvukoha tingimustes sõltuvad peamiselt pae murenemise astmest ning veerežiimist. 
Vaadeldavate proovitükkide hulgas võib tinglikult eraldada paare, mille kasvukohatingimused on enam-vähem ühesugused, kuid puistute tunnustes, nagu vanuses, koosseisus jne., esinevad teatavad erinevused. Paigutades. niisugused paarid kasvukohatingimuste halvenemise järjekorras, saame järgmise rea: $4 / 1-2 / 3-5-6 / 9-8 / 7$.

Langeva vare kogumiseks kasutati proovitükkidel nr. $1-41 \times 1 \mathrm{~m}$ suurusi ja $15 \mathrm{~cm}$ kõrgusi puidust kaste, millel olid pōhjas võrguga kaetud augud vihma ja sulamisvete äravooluks.

Proovitükkidel nr. 5-9 kasutati sama suuri tõrvapapist varekogujaid (foto 3). Törvapapilt on vare korjamine tülikam ja vee äravooluaukude kiire ummistumise tõttu vajavad nad sagedast hooldamist. Puitkastidega vōrreldes on tõrvapapp palju odavam ja temast valmistatud varekogujate

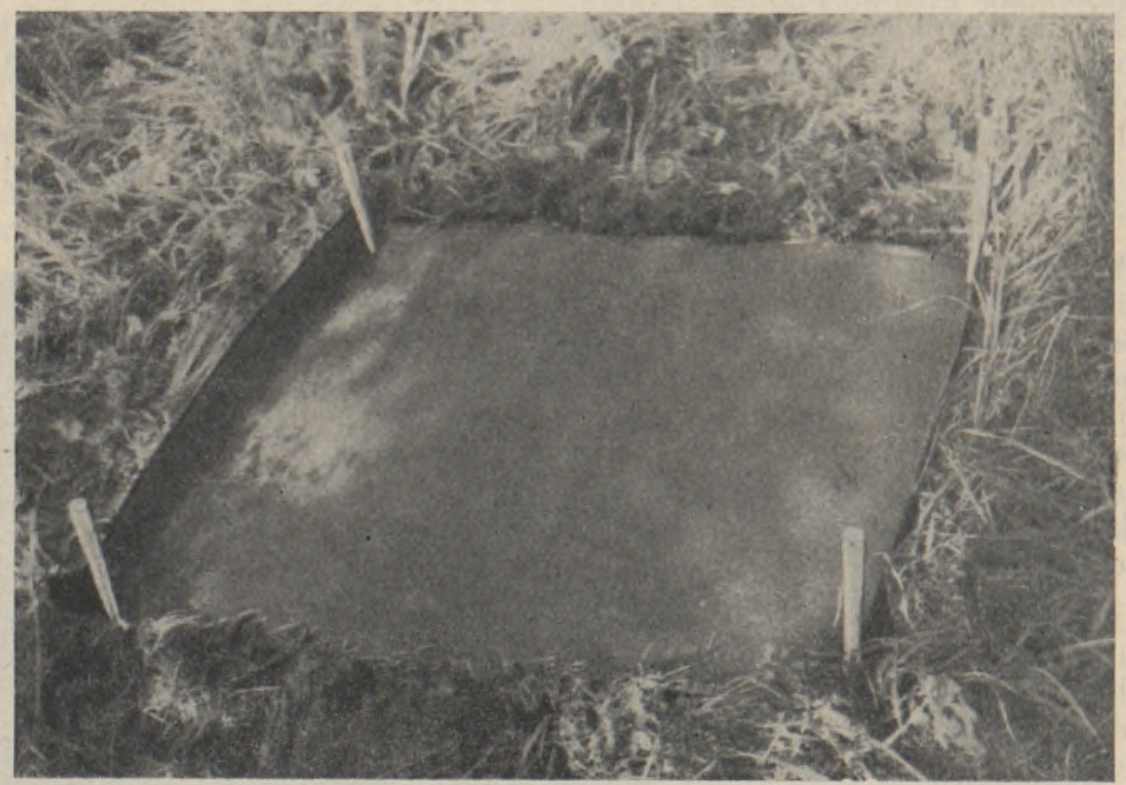

Foto 3. Tõrvapapist varekoguja.

paigutamine teedest kaugel asuvatesse puistutesse on hõlpsam.

Igale proovitükile asetati 10 varekogumiskasti resp. tõrvapappi. Suhteliselt väikese kogujate arvu ja loometsade ebaühtlase ehituse tôttu kasutati kogujate paigutamisel valikulist meetodit, et oleks võimalik hōlmata enam-vähem kõik puistu iseärasused. Seetōttu paigutati kogujaid ka häiludesse, järelkasvugruppide alla ja mujale.

Vare kogumine toimus periooditi: 1) 27. juulist 15. oktoobrini 1956 proovitükkidel nr. 1-4 iga 10 päeva järel (kokku 8 korda), proovitükkidel nr. 5-9 üks kord; 2) 16. oktoobrist 1956 16. maini 1957; 3) 17. maist 27. juulini 1957.

Kogutud õhukuiv vare eristati järgmiselt (sorteerimist hõlbustas tunduvalt mullasõelte komplekti kasutamine): 1) kuuseokkad, 2) männiokkad, 3) kuivanud oksad (neist $90 \% 1,5 \mathrm{~mm}$ jämedusega $1-12 \mathrm{~cm}$ pikkused kuuseoksad, $10 \%$ männioksad), 4) kooretükid (80\% männikorba soomuseid), 5) käbid, 6) määramata materjal (peenike purutaoline materjal, mis läbib $0,5 \mathrm{~mm}$ sõela ja milles võib eraldada väikesi kooretükke, käbisoomuste ja samblike osi). Loetletud koostisosad kaaluti ja määrati nende niiskussisaldus, 


\section{Vare hulk, koostis ja langemise dünaamika}

Uhe aasta jooksul maapinnale langeva vare hulgad (joon. 1) olid ligikaudu ühesuurused kõigil Koikse vahtkonnas asuvatel proovitükkidel (proovitükkidel nr. 1 ja $4-2623 \mathrm{~kg} / \mathrm{ha}$, proovitükil $\mathrm{nr} .2-2550 \mathrm{~kg} / \mathrm{ha}$ ja proovitükil $\mathrm{nr} .3-2415 \mathrm{~kg} / \mathrm{ha}$ ).

Abru vahtkonna proovitükkidel olid vare hulgad märgatavalt väiksemad ja erinevused nende vahel suuremad. Kõige vähem moodustus varet proovitükil nr. $7-886 \mathrm{~kg} / \mathrm{ha}$; peaaegu võrdselt oli varet proovitükkidel nr. 6 ja $9-1353$ ja $1387 \mathrm{~kg} /$ ha; proovitükil nr. 8 oli teda $1536 \mathrm{~kg} / \mathrm{ha}$ ja kõige rohkem varet oli langenud proovitükil nr. $5-1834 \mathrm{~kg} / \mathrm{ha}$.

Esitatud andmed näitavad, et vare hulk väheneb kasvukohatingimuste halvenedes; vōrdsete kasvukohatingimuste puhul on vare hulgad ühesuurused. Erandiks on proovitükk nr. 8, kus vare hulk oli ligi 2 korda suurem mullastikutingimustelt võrdlemisi sarnasest proovitükist nr. 7 ja suurem ka paremate kasvukohatingimustega proovitükkidest nr. 6 ja 9 .

Väiksem vare hulk halvemate kasvukohtade puhul on tingitud puude väiksematest dimensioonidest ega sõltu eriti puude arvust, kuna see võib ühevanuseliste puistute korral olla siin suurem kui heades kasvukohtades (näit. proovitükkidel nr. 1 ja 7 ).

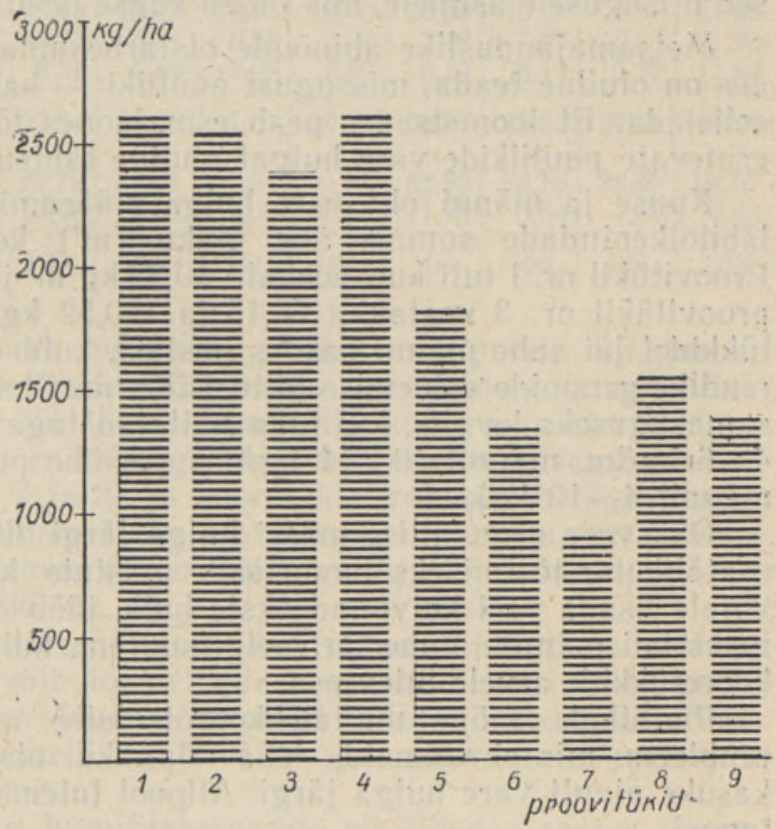

Joon. 1. Ohukuiva vare aastane hulk $\mathrm{kg} / \mathrm{ha}$. Põhjuseks pole ka niivõrd puude väike kõrgus ja diameeter kui nende hôredad võrad ja harv okastik.

Mitmete autorite (Зонн, 1954; Мина, 1954; Смирнова, 1951 a ja b) uurimised näitavad, et ühesuguste kasvukohatingimuste puhul oleneb metsa vare hulk mitmesugustest puistu omadustest, millest olulisemateks on metsa vanus ja liigiline koosseis. Vare hulk on suurim puistu jooksva juurdekasvu kulminatsioonil (40-60 a. vanuses) ja ta langeb puistu vananedes. Puistu koosseisu mõju vare hulgale oleneb puistu puuliikide bioloogilistest omadustest.

Loometsade vare hulk ei peegelda puistute iseärasusi; see oli võrdsete kasvutingimustega aladel ühesuurune (proovitükid nr. 1/4, $2 / 3$ ja 6/9). Uheks puistute mõju vähendavaks teguriks vare moodustumisel on loometsade ebaühtlane koosseis: mullastikutingimuste varieerumise tõttu esineb väikesel, mõnekümne ruutmeetri suurusel alal mitmesuguse kasvukäiguga puid, mille juurdekasvu langus saabub erinevatel aegadel (vahe vōib olla kuni 30 aastat) (Sepp, 1957).

Vörreldavate puistute paarides ei olnud vanuste erinevused suured (tabel 1), kuid ligilises koosseisus ja puude arvus on ilmsed vahed. 
Proovitükil nr. 1 (9 Ku 1 Mä) kasvab ühe hektari kohta 744 kuuske ja 112 mändi, proovitükil nr. 4 ( $5 \mathrm{Ku} 5 \mathrm{Mä)}$ on kuuskede arv ligikaudu sama suur (776), kuid mände on üle 5 korra rohkem (584). Analoogilisi erinevusi on ka teistel proovitükkidel, mille vare hulgad tegelikult on võrdsed (proovitükid nr. 2/3, 6/9).

Puuliikide vähemärgatav mõju vare üldhulgale on loometsades seletatav kehvade kasvutingimustega, mis ei võimalda kitsama ökoloogilise amplituudiga kuuse bioloogilistel iseärasustel täielikult avalduda: tema võra ja okastik jäävad siin alati hõredaks. Kasvukoha metsakasvatuslik eiekt, mille määravad loometsas eeskätt mullastikutingimused, asetab vare üldhulgale teatavad piirid, mida ei saa liigilise koosseisu reguleerimisega oluliselt muuta. Võimalus selleks avaneb alles siis, kui mullaviljakus tõuseb niisugusele astmele, mis lubab kuuse head kasvu ja arenemist.

Metsamajanduslike abinõude otstarbekamaks rakendamiseks loometsades on oluline teada, missugust puuliiki - kas mändi või kuuske - tuleb eelistada. Et loometsades peab esmajoones tõstma muldade viljakust, on erinevate puuliikide vare hulgal oluline tähtsus.

Kuuse ja männi okasvare hulga määramiseks tegime kindlaks nende läbilõikepindade summa ühe ühiku $\left(\mathrm{m}^{2}\right)$ kohta tuleva okaste koguse. Proovitükil nr. 1 tuli kuuseokkaid $40,82 \mathrm{~kg} / \mathrm{m}^{2}$ ja männiokkaid $139,50 \mathrm{~kg} / \mathrm{m}^{2}$, proovitükil nr. 3 vastavalt 53,15 ja $120,52 \mathrm{~kg} / \mathrm{m}^{2}$. Köikidel teistel proovitükkidel jäi suhe männi kasuks püsima, kuid oli kuuse järelkasvu ja noorendike gruppide esinemise tõttu väiksem. Okaste produktsiooni suhe jääb samasuguseks ka siis, kui tuua näitajad tagavara ühe tihumeetri (kuusel $4-6 \mathrm{~kg} / \mathrm{tm}$, männil $10-14 \mathrm{~kg} / \mathrm{tm}$ ) või ühe puu kohta (kuusel $1,5-2 \mathrm{~kg}$, männil $4-10 \mathrm{~kg}$ ).

Okasvare orgaanilise massi hulga järgi otsustades pole põhjust kuuse osatähtsuse tõstmiseks loometsade puistute koosseisus. Kui kuuseokaste varele lisada veel kuivanud okste hulk, jääb vare üldhulk siiski väiksemaks kui männil. Vahe on veelgi suurem, kui viimasele juurde arvestada kooretükkide arvele tulev osa.

Puuliikide mõju mullatekkeprotsessile on omaette komplitseeritud probleem, mis ei võimalda teha lõplikku otsust ühe või teise puuliigi kasuks ainult vare hulga järgi. Allpool tuleme selle küsimuse juurde veel tagasi.

Kirjanduse andmed vare hulga kohta (Зонн, 1954; Мелехов, 1957; Ремезов jt., 1949; Смирнова, 1951 а ја b) on üldjoontes erinevad, olenedes metsa tüübist, puistu metsakasvatuslikest omadustest ja geograafilisest rajoonist, kus vastavad uurimised teostati. Keskmisteks suurusteks loetakse kuusikutes $6000 \mathrm{~kg} / \mathrm{ha}$ ja männikutes $4100 \mathrm{~kg} / \mathrm{ha}$ (Зонн, 1954; Роде, 1955). Loometsade vare hulk on nendest näitajatest $2-5$ korda väiksem ja halvemates kasvukohtades (näit. proovitükil nr. 7) ka samblikumännikute vare hulgast madalam (Мелехов, 1957).

Eriti oluline paepealsetel muldadel on intensiivne aine ja energia ringkäik metsataimestiku ja mulla vahel. Sellest oleneb mullatekkeprotsessi kiirus ehk teiste sõnadega - muldade viljakuse tõus. Loometsades rakendatavad metsamajanduslikud abinõud peavad kindlustama niisuguse majandamisviisi, mille juures paepealsed on pidevalt metsaga kaetud ja ei vähene maapinnale langeva orgaanilise aine hulk. Esimeseks möödapääsematuks sammuks siin on loometsade viimine II grupi koosseisust I grupi alla. Loometsade mullakaitselisele tähtsusele ja eriliste raieviiside rakendamise vajadusele juhtisid metsakasvatajad tähelepanu juba palju aastaid tagasi (Kosenkranius, 1929; Schabak, 1928 ja 1933).

Vare osatähtsuse hindamisel metsataimestiku ja mulla vahel toimuvas ainete ringkäigus on oluline teada üksikute komponentide osa vare üldhul- 
gas (tabel 3), sest puurindest pärinev materjal ei ole ühesuguse keemilise koostise ja lagunemiskiirusega.

Vare aastase hulga mehaaniline koostis \%-des

Tabel 3

\begin{tabular}{|c|c|c|c|c|c|c|c|c|c|}
\hline \multirow{2}{*}{ Koostisosad } & \multicolumn{9}{|c|}{ Proovitükid } \\
\hline & 1 & 2 & 3 & 4 & 5 & 6 & 7 & 8 & 9 \\
\hline $\begin{array}{l}\text { Kuuseokkad } \\
\text { Männiokkad }\end{array}$ & $\begin{array}{l}38,60 \\
16,80\end{array}$ & $\begin{array}{l}32,89 \\
21,89\end{array}$ & $\begin{array}{l}34,69 \\
23,93\end{array}$ & $\begin{array}{l}28,45 \\
37,39\end{array}$ & $\begin{array}{l}25,94 \\
35,21\end{array}$ & $\begin{array}{l}29,21 \\
30,74\end{array}$ & $\begin{array}{l}19,05 \\
51,58\end{array}$ & $\begin{array}{l}10,13 \\
59,26\end{array}$ & $\begin{array}{l}18,95 \\
30,67 \\
\end{array}$ \\
\hline Kok k u & 55,40 & 54,78 & 58,62 & 65,84 & 61,15 & 59,95 & 70,63 & 69,39 & 49,62 \\
\hline $\begin{array}{l}\text { Kuivanud oksad } \\
\text { Kooretükid } \\
\text { Määramata materjal }\end{array}$ & $\begin{array}{r}14,85 \\
3,26 \\
8,95\end{array}$ & $\begin{array}{r}15,42 \\
6,21 \\
6,31 \\
\end{array}$ & $\begin{array}{r}15,92 \\
5,71 \\
7,69\end{array}$ & $\begin{array}{r}12,42 \\
6,69 \\
6,99 \\
\end{array}$ & $\begin{array}{r}16,99 \\
6,74 \\
6,97\end{array}$ & $\begin{array}{r}15,50 \\
7,18 \\
6,19\end{array}$ & $\begin{array}{r}10,27 \\
7,09 \\
8,17\end{array}$ & $\begin{array}{r}9,43 \\
12,31 \\
7,27\end{array}$ & $\begin{array}{l}21,52 \\
11,90 \\
11,63\end{array}$ \\
\hline Kokku & 27,06 & 27,94 & 29,32 & 26,10 & 30,70 & 28,87 & 25,53 & 29,01 & 45,05 \\
\hline $\begin{array}{l}\text { Okkad ja muu kokku } \\
\text { Käbid }\end{array}$ & $\begin{array}{l}82,46 \\
17,54\end{array}$ & $\begin{array}{l}82,72 \\
17,28\end{array}$ & $\begin{array}{l}87,94 \\
12,06\end{array}$ & $\begin{array}{r}91,94 \\
8,06 \\
\end{array}$ & $\begin{array}{r}91,85 \\
8,15 \\
\end{array}$ & $\begin{array}{l}88,82 \\
11,18\end{array}$ & $\begin{array}{r}96,16 \\
3,84 \\
\end{array}$ & $\begin{array}{r}98,40 \\
1,60 \\
\end{array}$ & $\begin{array}{r}94,67 \\
5,33 \\
\end{array}$ \\
\hline Kōik kokku & 100 & 100 & 100 & 100 & 100 & 100 & 100 & 100 & 100 . \\
\hline
\end{tabular}

Vare koostisosade vahekorra määravad esmajoones puistu omadused; kasvukohatingimuste mõju on kaudne. Esimestest on oluline puistu liigiline koosseis, mis määrab ühele või teisele puuliigile kuuluva materjali osa vare üldhulgas. Nii on männi enamusega puistute vare koostises kuivanud oksi vähem (proovitükid nr. 7 ja 8 ) ja kooretükke rohkem kui kuusikutes (proovitükid nr. 1, 2, 3). Kuivanud okste protsent on suurem, kui puistus esineb tihedalt kuuse järelkasvu (proovitükk nr. 6) või rohkesti IV-V kasvuklassi kuuski (proovitükk nr. 9).

Oksikute komponentide protserit vare üldhulgas muutub suhteliselt väikestes piirides, mistõttu võib loometsade keskealiste kuni raieküpsete puistute vare koostise kohta avaldada järgmised näitajad: okkaid $50-70 \%$, kuivanud oksi $13-20 \%$, kooretükke $5-10 \%$ ja määramata materjali $6-10 \%$.

Metsa vare lagunemine ja humifitseerumine on tihedas seoses ilmastiku, mullafauna ja eriti mikrofloora elutegevuse sesoonsete seaduspärasustega. Seepärast on vaja teada eri perioodidel maapinnale langeva vare hulka ja koostist, milleks korraldati Koikse vahtkonna proovitükkidel vastav uurimine. Selle kohta tabelis 4 ja joonistel $2-6$ esitatud andmed võimaldavad teha rea järeldusi.

Vare langemine ei toimu aasta kestel ühesuguse intensiivsusega. Kõige enam varises suvisügisesel perioodil (27. juulist 15. oktoobrini): 80 päeva jooksul moodustus $40-50 \%$ varet aastasest kogusest. Talvise perioodi (16. oktoobrist 16. maini) 212 päeva jooksul langes $30-40 \%$ varet ja kevadsuvise perioodi (17. maist 27. juulini) 71 päeva jooksul $20 \%$ aảstasest vare hulgast. $60-70 \%$ varest langes vegetatsiooniperioodil, millal valitsevad soodsad mikrobioloogilised tingimused orgaanilise aine lagunemiseks. See on üks pōhjusi, miks loometsade vare mineraliseerumine toimub kiiresti ja metsakōdu hulk on väike.

Vare koostis eri perioodidel ei ole ühesugune. Okaste aastasest kogusest langes suvisügisel $50-55 \%$, talvel $25-30 \%$. ja kevadsuvel $20 \%$, kuid üksikute puuliikide järgi on vahekorrad teistsugused.

Kuuseokkaid langes suvisügisesel perioodil $40-50 \%$, talvel $40-45 \%$ ja kevadsuvel 5-20\%. Kuna peaaegu pool raskesti lagunevate kuuseokaste aastasest hulgast langeb talvel, on nende mineraliseerumine veelgi aegla- 


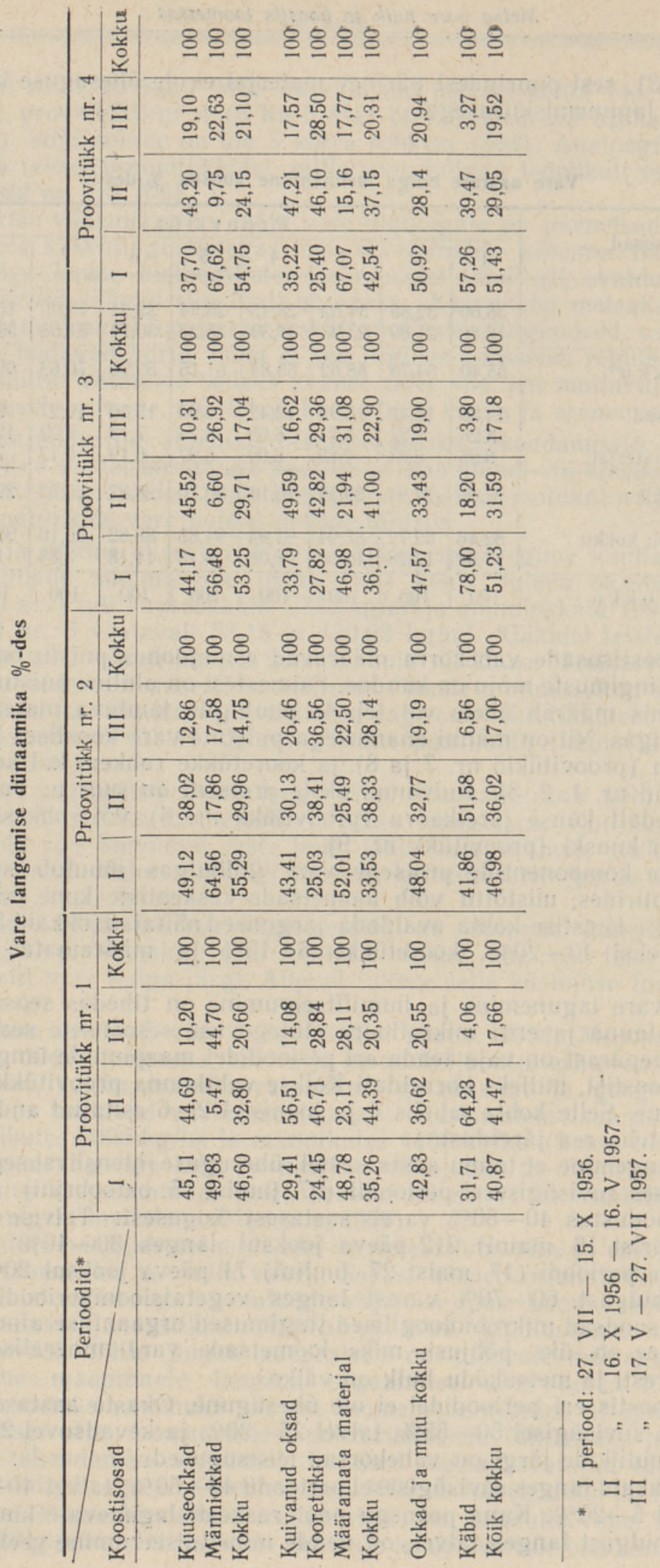


sem; mistõttu metsakõdu koostises - eriti kevadel ja sügisel - leidub alati rohkem kuuseokkaid.

Männiokaste lagunemine toimub paremates tingimustes, sest vegetatsiooniperioodil langes neid $80-90 \%$ (suvisügisel $60-70 \%$, kevadsuvel $20-30 \%$ ) ja talvel ainult $10 \%$.

Loometsade vare raskemini mineraliseeruvat materjali - kuivanud oksi - langes vegetatsiooniperioodil $50-60 \%$, talvel $40-45 \%$. Kooretükkide varisemine, mille lagunemine toimub samuti aeglaselt, oli suvisügisel ja kevadsuvel peaaegu võrdne $(25-35 \%)$ ja talvel mõnevõrra suurem $(40-45 \%)$. Määramata materjalist langes suvisügisel $50-60 \%$, kevadsuvel $20-30 \%$ ja talvel $15-25 \%$. Kuigi siin põhimassi moodustavad raskemini lagunevate materjalide tükikesed (kooretükid, käbisoomused jm.), võib oletada, et nende mineraliseerumine toimub kiiresti osa. keste väikese suuruse tõttu.

Metsakõdu üldhulga tunduvat vähenemist kesksuvel ei saa seletada ainult paremate lagunemistingimustega (loometsades puudub sel ajal $\mathrm{A}_{0}$-horisont sageli täielikult), nagu näiteks väidavad Abramova (1947) ja Moltšanov (1952). Siinjuures tuleb kindlasti arvestada asjaolu, et just sel perioodil on vare hulk kôige väiksem ja tema pōhilise osa moodustab paremini lagunev materjal. Seda tõendavad peale eespool toodud keskmiste näitajate ka vare langemise dünaamikat suvisügisperioodil kujutavad joonised $2-6$.

Sügise saabudes toimus kõikidel proovitükkidel ühetaoliselt vare üldhulga perioodiline suurenemine (joon. 2), mis moodustas ainuüksi vaatlusperioodi viimase kümne päeva jooksul (5.-15. oktoobrini) üle $60 \%$ kevadsuvise perioodi (72 päeva) vältel kogunenud hulgast. Nii näiteks oli 10-päevane vare hulk proovitükil nr. $1296 \mathrm{~kg} / \mathrm{ha}$ ja kevadsuveperioodil $463 \mathrm{~kg} / \mathrm{ha}$; proovitükil nr. 3 olid vastavad näitajad 256 ja $415 \mathrm{~kg} / \mathrm{ha}$.

Analoogiliselt vare üldhulga langemisele oli samade koostisosade langemine eri proovitükkidel enam-vähem ühesugune (joon. 3-6). Uksikute koostisosade langemine samal proovitükil oli aga erinev, mistõttu vare üldhulga perioodiline suurenemine siin ei kajastu.

Vegetatsiooniperioodi lõpul väheneb vares okaste osatähtsus ja suureneb kuivanud okste, kooretükkide ning määramata materjali hulk. Vähenemine toimub männiokaste arvel, kuuseokaste osa seevastu suureneb. Köikidel proovitükkidel oli okaste vahekorras pöördepunktiks 15. september: sellest kuupäevast alates toimus männiokaste protsendi järsk langus, kuna kuuseokaste protsent tõusis. Vaatlusperioodi viimase kümne päeva jooksul varises sama palju kuuseokkaid kui kogu kevadsuvise perioodi vältel: proovitükil nr. 1 oli 10-päevane okaste hulk $109 \mathrm{~kg} / \mathrm{ha}$ ja kevad- 


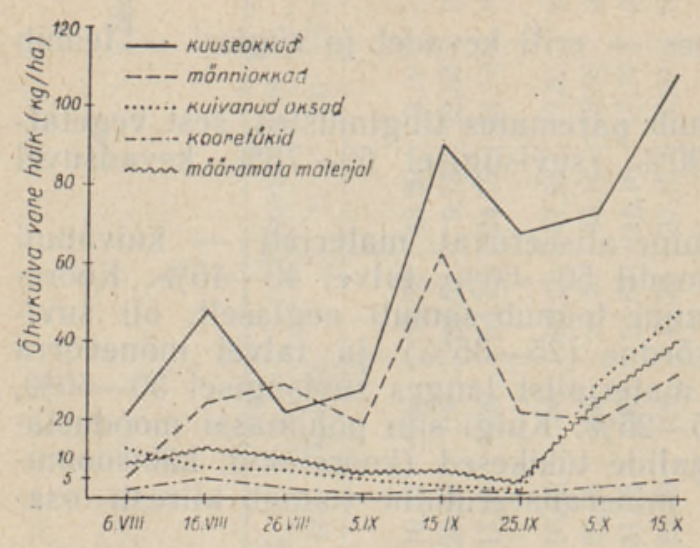

Joon. 3, Vare koostisosade langemise dünaamika proovitükil $\mathrm{nr}$. 1 .

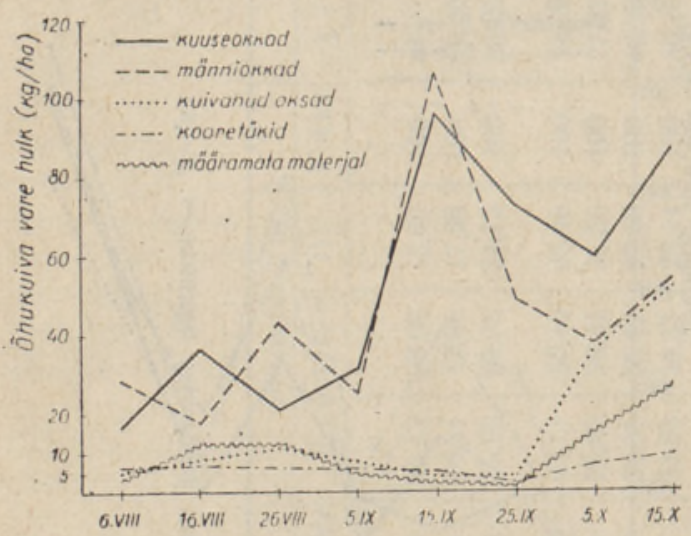

Joon. 4. Vare koostisosade langemise dünaamika proovitükil nr. 2 .

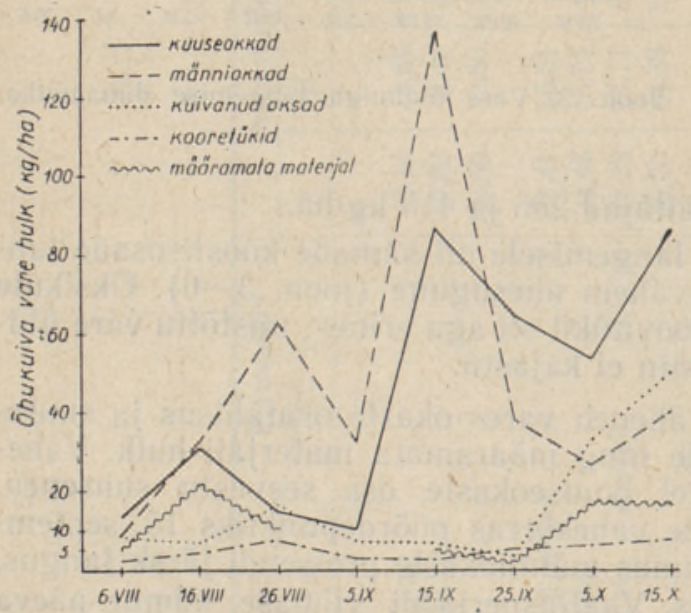

Joon. 5. Vare koostisosade langemise dünaamika proovitükil $\mathrm{nr}$. 3 . suvine kogus $103 \mathrm{~kg} / \mathrm{ha}$; proovitükil nr. 3 olid vastavad andmed 387 ja 86 kg/ha. Männiokkaid langes aga $4-5$ korda vähem.

Kuivanud okste, kooretükkide ja määramata materjali hulga märgatav tõus algas kõikidel proovitükkidel 25. septembril. Vaatlusperioodi lõpul kogutud materjalis oli kuivanud oksi peaaegu sama palju kui kogu kevadsuvises vares (proovitükil nr. 1 - vaatlusperioodi lõpul $47 \mathrm{~kg} / \mathrm{ha}$, kevadsuvel 53 $\mathrm{kg} / \mathrm{ha}$; proovitükil nr. 3 vastavalt 51 ja $64 \mathrm{~kg} / \mathrm{ha})$.

Kuna vare langemine oli kõikidel proovitükkidel pōhijoontes ühesugune, võib seda lugeda iseloomulikuks kogu loometsade tüübirühmale. Vaatamata ühesugustele puuliikidele ja meteoroloogilistele tingimustele, võib see teistes metsatüüpides olla mõnevõrra erinev (Мелехов, 1957).

Vare hulka ja langemise seaduspärasusi vỗivad muuta juhuslikud pōhjused, nagu kahjurite rüüste, seenhaigused, lageraie kõrvalasuvates puistutes vm. Proovitükil nr. 8 oli näiteks 1956. a. septembri-oktoobri vares erakordselt suur kogus männiokkaid ( $583 \mathrm{~kg} / \mathrm{ha})$, mis ületas vastava hulga teistel proovitükkidel 4-5-kordselt. Selline intensiivne männiokaste langus ühel proovitükil oli ilmselt vastuolus nende varisemisega teistel proovitükkidel. Põhjuseks osutus siin pudetõve (Lophodermium pinastri) tugev kahjustus, mille tagajärjel eelmisel aastal nakatatud okkad sügiseks kolletasid ja maha langesid.

Uhe aasta vaatlusandmed ei võimalda veel teha lõplikke järeldusi vare üldhulga kohta, sest peale juhuslike põhjuste mõjustavad seda veel meteoroloogilised tingimused. Tavaliselt koguneb varet kuivematel aastatel vähem kui niisketel 
(Зонн, 1954; Ковалевский, 1953). Kuna 1956. aasta oli sademeterikas, võib oletada, et ka mitme aasta keskmine vare hulk loometsades ei kujune meie andmetest väiksemaks. (1957. aasta uurimised näitasid, et suvisügisesed vare hulgad olid peaaegu võrdsed vastavate 1956. aasta hulkadega.)

Joon. 6.

Vare koostisosade langemise dünaamika proovitükil nr. 4 .

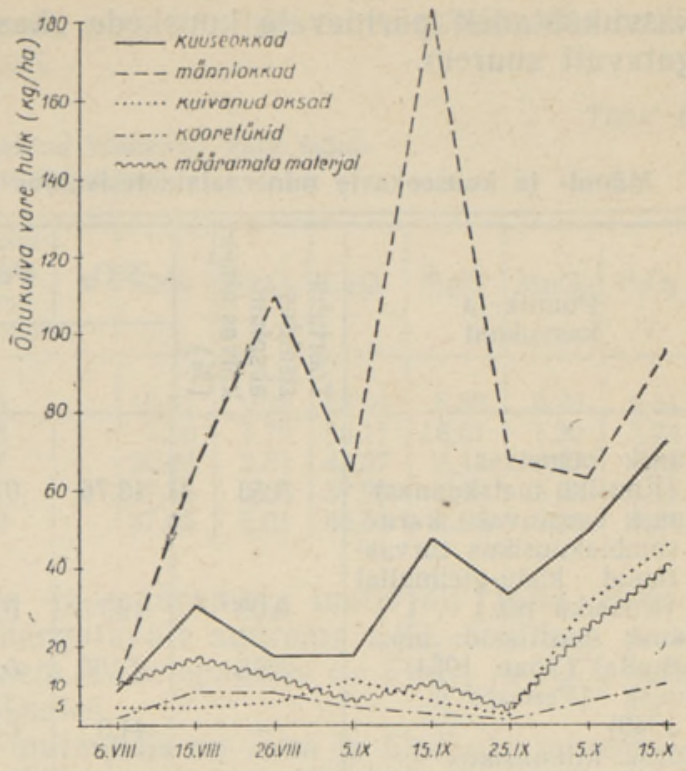

\section{Mineraalainetesisaldus vares}

Veel hiljuti levis mulla- ja metsateadlaste hulgas arvamus, et mineraalainetesisaldus ühe ja sama puuliigi okastes on muutumatu ega olene kasvukohatingimustest (Степанов, 1939; Ткаченко, 1952). Käesolevaks ajaks on kogunenud rohkesti faktilist materjali, mis tõendab, et ühel ja samal puuliigil oleneb kasvukohatingimustest mitte ainult mineraalainete üldsisaldus okastes, vaìd üksikute elementide vahekordki peegeldab muldade iseärasusi (Зонн, 1954; Шумаков, 1941; Китредж, 1951).

Kuuse ja männi elusokaste mineraalainetesisalduse võrdlus loometsades ja teistes kasvukohtades näitab lahkuminekuid (tabel 5).

Lookuuskede okastes on mineraalainete üldsisaldus (tuha \%) suhteliselt kõrge $(3,53 \%)$ ja võrdne parimate kasvukohtade kuuskedega. Seevastu loometsade männiokastes on mineraalaineid ligi kaks korda vähem, võrreldes teiste kasvukohtadega, ja üle 2,5 korra vähem kui loometsade kuuseokastes.

$\mathrm{SiO}_{2}$-sisaldus on loomuldadel mõlema puuliigi (eriti männi) okastes tublisti madalam kui teistel muldadel kasvavatel puudel. Kuuseokaste $\mathrm{SiO}_{2}$-sisaldus $(13,76 \%)$ on lähedane kehvadel leedemuldadel kasvavate puude omaga.

$\mathrm{Fe}_{2} \mathrm{O}_{3}$ leidub nii loopealse kuuse kui ka männi okastes ligikaudu niisama palju kui teistelt muldadelt pärinevas materjalis. Seetõttu on kaheldav Rode (1955, lk. 271) väide, et huumus-karbonaatmuldadel kannatavad puud, eriti mänd, raua puuduse all, mis väljendub okaste kloroosis. Viimaste heleroheline või kollakas värvus võib olla tingitud ka mitmest muust tegurist.

Vōrreldes teiste kasvukohtadega on $\mathrm{CaO}$-sisaldus loomuldadel kuuse okastes $20-25 \%$ võrra suurem, männil aga mõnevõrra väiksem.

MgO hulk lookuuse okastes on võrdne tema sisaldusega parematelt 
kasvukohtadelt pärinevate kuuskede okastes; männiokastes on see märgatavalt suurem.

Tabel 5

Männi- ja kuuseokaste mineraalainetesisaldus erinevates kasvukohatingimustes *

\begin{tabular}{|c|c|c|c|c|c|c|c|}
\hline \multirow{2}{*}{$\begin{array}{l}\text { Puuliik ja } \\
\text { kasvukoht }\end{array}$} & \multirow{2}{*}{ 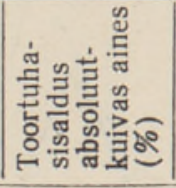 } & $\mathrm{SiO}_{2}$ & $\mathrm{Fe}_{2} \mathrm{O}_{3}$ & $\mathrm{CaO}$ & $\mathrm{MgO}$ & $\mathrm{MnO}$ & $\mathrm{P}_{2} \mathrm{O}_{5}$ \\
\hline & & \multicolumn{6}{|c|}{$\%$ tuha ka alust } \\
\hline \multirow{4}{*}{$\begin{array}{l}\text { Kuusk loometsas } \\
\text { (Kuusiku metskonnas) } \\
\text { Kuusk soostuvas karu- } \\
\text { samblakuusikus turvas- } \\
\text { tunud kõdu-gleimullal } \\
\text { (Kuusiku mk.) } \\
\text { Kuusk leostunud must- } \\
\text { mullal ((3онн, 1954) } \\
\text { Kuusk (Pемезов jt., }\end{array}$} & 3,53 & 13,76 & 0,89 & 52,29 & 4,75 & 0,97 & 5,05 \\
\hline & 3.09 & $18.77^{\circ}$ & 065 & 30,42 & 6.51 & 1.24 & \\
\hline & 3,07 & 10,17 & 0,00 & 30,97 & 6,01 & 1,24 & 7,44 \\
\hline & & & & & & 4,17 & - \\
\hline Kuusk liitkuusikus & - & 44,3 & 0,80 & 29,10 & 1,70 & 0,60 & - \\
\hline $\begin{array}{l}\text { (Смирнова, 1951 а ја b) } \\
\text { Kuusk tugevasti leetunud }\end{array}$ & 3,54 & 20,09 & 0,23 & 28,88 & 4,81 & 2,67 & - \\
\hline $\begin{array}{l}\text { 1955) } \\
\text { Mänd loometsas (Kuusi- }\end{array}$ & 3,02 & 14,9 & - & 31,8 & 5,3 & 4,3 & 6,6 \\
\hline $\begin{array}{l}\text { ku mk.) } \\
\text { Mänd leostunud must- }\end{array}$ & 1,33 & 2,76 & 0,89 & 24,34 & 9,35 & 0,78 & 16,12 \\
\hline $\begin{array}{l}\text { mullal (Зонн, 1954) } \\
\text { Mänd (Шумаков, 1941) }\end{array}$ & $\begin{array}{l}2,43 \\
2,30\end{array}$ & 8,60 & 1,00 & $\begin{array}{l}26,60 \\
47,34\end{array}$ & $\begin{array}{l}7,10 \\
5,60\end{array}$ & 3,60 & $3, \overline{25}$ \\
\hline
\end{tabular}

* Loometsade kohta on toodud viielt puult kogutud andmete keskmine summa, kusjuures analüüside tulemused ei erinenud üle $2 \%$.

MnO-sisaldus on eespool nimetatud mineraalainetest üldiselt väiksem, eriti männil.

Väga kõrge fosforisisaldusega on männiokkad; selle poolest ületavad nad isegi viljakatel muldadel kasvanud tammede lehed (Мина, 1951). Kuuseokaste $\mathrm{P}_{2} \mathrm{O}_{5}$-sisaldus loomuldadel on natuke madalam kui kehvadel leetmuldadel.

Okaste suremisel toimuvad nende koostises muutused, mistõttu vareokaste mineraalne koostis erineb elusokastest. Uheks okaste keemilise koostise muutumise põhjuseks on sügisene toiteelementide ja orgaaniliste ainete äravool. Orgaanilise osa vähenemise arvel tõuseb vareks muutunud okaste tuhasisaldus (tabel 6).

Tamme ja vahtra mahalangenud lehtede koostise muutumist pōhjendatakse veel toitainete väljauhtumisega sademete poolt (Мина, 1951). Kiиidas see okastes toimub, ei ole täpselt teada, kuid arvestades nende pikka iga (männil 2-5, kuusel 5-12 aastat), võivad siin avaldada tunduvalt mõju nii sisemised biogeensed kui ka välised tegurid. Burges'i (1956) uurimused näitavad, et okastest uhutakse välja suurem osa fosforit kohe pärast rakkude suremist. Tõenäoliselt on sellega seletatav ka meie tabeleist 5 ja 6 ilmnev suur erinevus elusokaste ja vare fosforisisalduses.

Kuuseokastes on muutused väiksemad ja peale fosfori väheneb märgatavalt ainult raua hulk. $\mathrm{SiO}_{2}$ osa suureneb mōnevõrra.

Männi elus- ja vareokaste koostises on erinevused suuremad. Fosfori- 
sisaldus väheneb vares neljakordselt, kõikide teiste mineraalühendite hulk aga suureneb peaaegu kahekordselt.

Tabel 6

Mineraalainetesisaldus loometsa vare tuhas (protsentides)

\begin{tabular}{l|c|r|r|r|r|r|r}
\hline Vare koostisosad & $\begin{array}{r}\text { Toortuha- } \\
\text { sisaldus } \\
\text { absoluut- } \\
\text { kuivas aines }\end{array}$ & $\mathrm{SiO}_{2}$ & $\mathrm{Fe}_{2} \mathrm{O}_{3}$ & $\mathrm{CaO}$ & $\mathrm{MgO}$ & $\mathrm{MnO}$ & $\mathrm{P}_{2} \mathrm{O}_{5}$ \\
\hline & & & & & & & \\
\hline Kuuseokkad & 4,43 & 15,61 & 0,39 & 52,94 & 5,39 & 0,80 & 2,01 \\
Männiokkad & 1,48 & 7,26 & 1,79 & 56,11 & 16,61 & 1,30 & 3,74 \\
Kuivanud oksad & 2,07 & 27,08 & 2,81 & 44,27 & 4,43 & 0,67 & 4,68 \\
Kooretükid & 3,17 & 37,58 & 1,86 & 37,93 & 2,10 & 0,28 & 1,24 \\
Määramata materjal & 3,10 & 37,65 & 2,01 & 36,54 & 1,98 & 0,26 & 1,32
\end{tabular}

Kuivanud okste, kooretükkide ja määramata materjali tuha mineraalne koostis erineb okastest märgatavalt suurema $\mathrm{SiO}_{2}$-sisalduse poolest. $\mathrm{CaO}$ hulk on tunduvalt väiksem. Tähelepandav on $\mathrm{Fe}_{2} \mathrm{O}_{3}$ ja $\mathrm{P}_{2} \mathrm{O}_{5}$ hulk okaste tuhas, olles kõrgem kui okastes.

Kooretükkides ja määramata materjalis on tuha ja üksikute mineraalühendite sisaldus praktiliselt ühesugune, mis tõenäoliselt on tingitud kooretükikeste suurest osatähtsusest määramata materjalis. $\mathrm{MgO}-, \mathrm{MnO}-$ ja $\mathrm{P}_{2} \mathrm{O}_{5}$-sisaldus samas on väiksem kui okastes ja okstes; $\mathrm{Fe}_{2} \mathrm{O}_{3}$ hulk on märgatavalt suurem ja võrdne tema sisaldusega männiokastes.

Vare koostisosadega mulda tagastatavate mineraalainete hulga määramisel omab tähtsust viimaste hulk õhukuivas* aines, mille kohta on toodud andmed tabelis 7 .

Tabel 7

Mineraalainetesisaldus loometsa vares

(\%-des ōhukuiva aine kohta)

\begin{tabular}{l|c|c|c|c|c|c}
\hline \multicolumn{1}{c|}{ Vare koostisosad } & $\mathrm{SiO}_{2}$ & $\mathrm{Fe}_{2} \mathrm{O}_{3}$ & $\mathrm{CaO}$ & $\mathrm{MgO}$ & $\mathrm{MnO}$ & $\mathrm{P}_{2} \mathrm{O}_{5}$ \\
\hline & 0,68 & 0,018 & 2,30 & 0,24 & 0,035 & 0,088 \\
Kuuseokkad & 0,11 & 0,027 & 0,83 & 0,25 & 0,019 & 0,056 \\
$\begin{array}{l}\text { Männiokkad } \\
\text { Kuivanud oksad }\end{array}$ & 0,55 & 0,059 & 0,92 & 0,09 & 0,013 & 0,098 \\
$\begin{array}{l}\text { Kooretükid ja määramata } \\
\text { materjal }\end{array}$ & 1,20 & 0,059 & 1,21 & 0,07 & 0,09 & 0,039 \\
\end{tabular}

$\mathrm{SiO}_{2}$ tagastatakse kõige enam kooretükkidega; okstega ja kuuseokastega tagastatakse teda kaks korda vähemas koguses ja männiokastega kümme korda vähemas koguses. $\mathrm{Fe}_{2} \mathrm{O}_{3}$ leidub maapinnale langenud okstes ja kooretükkides üle kahe korra văhem kui okastes. Lubjaga rikastavad mulla ülemist horisonti kõige enam kuuseokkad ja kooretükid. Männi okastes ja okstes sisaldub $\mathrm{CaO}$ võrdselt, seejuures poole vähem kui kuuse okastes. Magneesiumi on okastes kolm korda rohkem kui okstes ja kooretükkides. MnO-sisalduse poolest on esikohal kuuseokkad; muus materjalis leidub seda märgatavalt vähem. Fosforit tuleb maapinnale kõige rohkem kuuseokaste ja okste varega.

Aasta jooksul varega maapinnale langevate mineraalainete üldhulk on loometsades tublisti kõikuv (joon. 7). Kehvemates kasvukohtades (proovitükk $\mathrm{nr}$. 7) tuleb aastas hektari kohta $20 \mathrm{~kg}$ mineraalaineid ja

* Vare kaaluti pärast kümnepäevast kuivatamist, millal õhukuiva materjali niiskussisaldus osutus eri perioodidel kogutud vares praktiliselt võrdseks. 
paremates lookuusikutes kuni $70 \mathrm{~kg}$ (proovitükk nr. 1). Isegi viimane arv on tagasihoidlik, kui arvestada okaspuistutes keskmiseks näitajaks 90$100 \mathrm{~kg} / \mathrm{ha}$ (Зонн, 1954).

Maapinnale langevate mineraalainete hulk on proovitükkidel üldiselt vastavuses vare hulgaga (vt. joon. 1). Kuna kuuseokastes on mineraal-

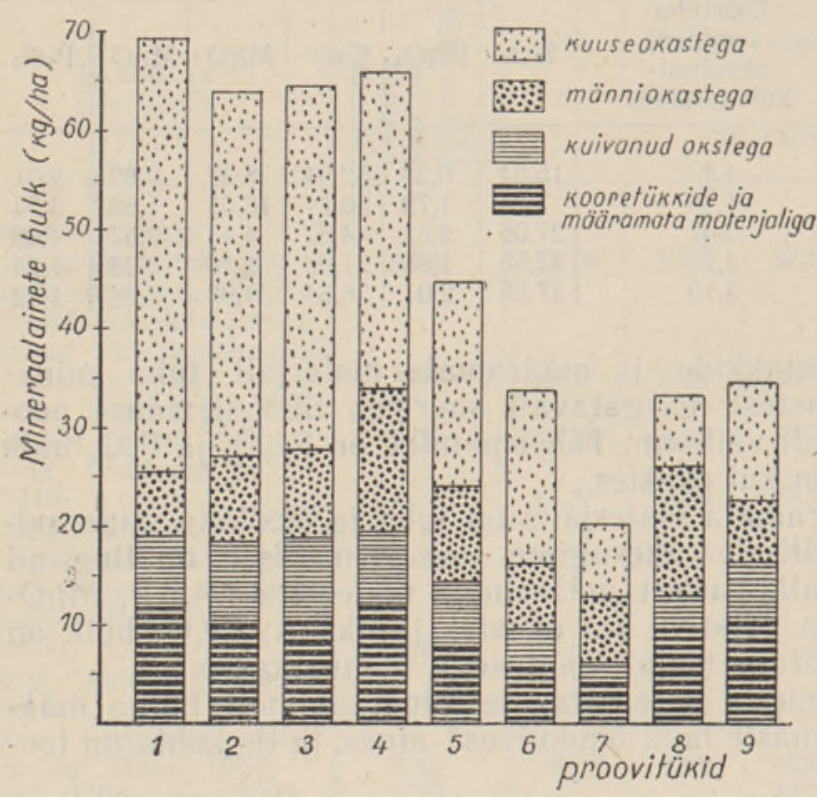

Joon. 7. Aasta jooksul varega maapinnale langevate mineraalainete hulk. aineid tunduvalt rohkem kui männiokastes ja muus materjalis, on proovitükkidel $\mathrm{nr} .2,4$ ja 9 kõrgem mineraalainete üldhulk (võrreldes vare hulgaga) põhjustatud kuuse suuremast osatähtsusest puistute koosseisus.

On tähelepanuväärne, et kuivanud okste ja kooretükkide poolt mulda tagastatav mineraalainete hulk on küllaltki suur, moodustades keskmiselt $30 \%$ (proovitükkides nr. 8 ja 9 üle $40 \%$ ) tagastatavate mineraalainete üldhulgast.

Metsataimestiku ja mulla vaheliste suhete selgitamisel ja üksikute puuliikide osatähtsuse hindamisel muldade arengus on oluline tea-

da mulda tagastatava üldise mineraalainete hulga körval ka üksikute elementide osatähtsust.

Vastavad andmed toome ainult proovitükkide nr. 1 ja 7 kohta arvestusega, et need on loometsade tüübirühmas n. ö. äärmuskasvukohtadeks (tabel 8).

Toodud andmed näitavad, et käsitletavatest elementidest tagastatakse varega mulda kõige rohkem kaltsiumi. See toimub peamiselt kuuseokaste näol, sest võrreldes teiste vare koostisosadega on CaO-sisaldus kuuseokastes märgatavalt suurem. Kõrge karbonaatidesisaldusega loomuldade pealmise horisondi rikastamine kaltsiumiga ei ole aga soovitav.

$\mathrm{SiO}_{2}$ tagastatakse ligi kolm korda vähem kui kaltsiumi. Kuuse okste kõrval on siin suur osatähtsus ka kooretükkidel. Näiteks langes proovitükil $\mathrm{nr} .7$ viimastega mullapinnale peaaegu sama palju $\mathrm{SiO}_{2}(1,61 \mathrm{~kg} / \mathrm{ha})$ kui okastega kokku (1,65 kg/ha). Loomulla peeneselise osa suurendamise ja karbonaatsuse vähendamise seisukohalt on teatav tähtsus mulda tagastataval $\mathrm{SiO}_{2}$ hulgal, mille poolest kõige rikkamad on kuuseokkad.

Teisi mineraalühendeid tagastatakse palju väiksemates kogustes. Järjestades viimased vähenemise suunas, saab järgmise rea: $\mathrm{MgO}-\mathrm{P}_{2} \mathrm{O}_{5}-$ $\mathrm{Fe}_{2} \mathrm{O}_{3}-\mathrm{MnO}$.

Võrreldes omavahel proovitükke nr. 1 ja 7 näeme, et viimasel langeb varega mulda kõiki mineraalühendeid umbes kolm korda vähem. $\mathrm{SiO}_{2}$ ja $\mathrm{MnO}$ hulkade erinevused on veelgi suuremad, sest nende peamiseks allikaks on kuuseokkad, mida kõnesolevate proovitükkide vares leidub vähem. Teistel proovitükkidel moodustavad tagastatavad mineraalainete hulgad 
Tabel 8

Aasta jooksul varega mulda tagastatavate mineraalainete hulk ( $\mathrm{kg} / \mathrm{ha}$ ) proovitükkidel $\mathrm{nr} .1$ ja $\mathrm{nr} .7$

\begin{tabular}{|c|c|c|c|c|c|c|c|}
\hline \multicolumn{2}{|r|}{ Vare koostisosad } & $\mathrm{SiO}_{2}$ & $\mathrm{Fe}_{2} \mathrm{O}_{3}$ & $\mathrm{CaO}$ & $\mathrm{MgO}$ & $\mathrm{MnO}$ & $\mathrm{P}_{2} \mathrm{O}_{5}$ \\
\hline \multirow{6}{*}{ 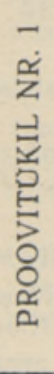 } & $\begin{array}{l}\text { Kuuseokkad } \\
\text { Männiokkad }\end{array}$ & $\begin{array}{l}6,880 \\
0,483 \\
\end{array}$ & $\begin{array}{l}0,182 \\
0,118 \\
\end{array}$ & $\begin{array}{r}23,270 \\
3,640 \\
\end{array}$ & $\begin{array}{l}2,420 \\
1,090\end{array}$ & $\begin{array}{l}0,350 \\
0,084 \\
\end{array}$ & $\begin{array}{l}0,890 \\
0,246 \\
\end{array}$ \\
\hline & Kokku & 7,363 & 0,300 & 26,910 & 3,510 & 0,434 & 1,136 \\
\hline & Kuivanud oksad & 2,140 & 0,229 & 3,570 & 0,350 & 0,050 & 0,382 \\
\hline & ramata materjal & 3,840 & 0,189 & 3,870 & 0,220 & 0,029 & 0,124 \\
\hline & Kokku & 5,980 & 0,418 & 7,440 & 0,570 & 0,079 & 0,506 \\
\hline & Kōik kokku & 13,343 & 0,718 & 34,350 & 4,080 & 0,513 & 1,642 \\
\hline \multirow{6}{*}{ 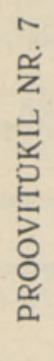 } & $\begin{array}{l}\text { Kuuseokkad } \\
\text { Männiokkad }\end{array}$ & $\begin{array}{l}1,149 \\
0,503 \\
\end{array}$ & $\begin{array}{l}0,030 \\
0,123 \\
\end{array}$ & $\begin{array}{l}3,888 \\
3,796 \\
\end{array}$ & $\begin{array}{l}0,405 \\
1,143 \\
\end{array}$ & $\begin{array}{l}0,059 \\
0,086 \\
\end{array}$ & $\begin{array}{l}0,148 \\
0,256 \\
\end{array}$ \\
\hline & Kokku & 1,652 & 0,153 & 7,684 & 1,548 & 0,145 & 0,404 \\
\hline & Kuivanud oksad & 0,500 & 0,053 & 0,837 & 0,081 & 0,018 & 0,089 \\
\hline & ramata materjal & 1,611 & 0,079 & 1,625 & 0,094 & 0,012 & 0,052 \\
\hline & Kokku & 2,111 & 0,132 & 2,462 & 0,175 & 0,030 & 0,141 \\
\hline & Kōik kokku & 3,763 & 0,285 & 10,146 & $-1,723$ & 0,175 & 0,545 \\
\hline
\end{tabular}

mitmesuguseid vaheastmeid proovitükkide nr. 1 ja 7 vastavate hulkade vahel.

Mitmekordne erinevus metsa ja mulla vahel toimuva ainevahetusprotsessi intensiivsuses ühel ja samal mullaerimil asuvatel proovitükkidel nr. 1 ja 7 on järjekordseks tõendiks, et loomuldade metsakasvatuslikke omadusi ei saa iseloomustada ainult peeneselise horisondi tüsedusega.

Eespool ilmnes, et langeva vare hulga poolest ei ole kuusel männiga võrreldes olulisi eeliseid. Mineraalainetesisaldus oli küll kuuseokastes märgatavalt suurem kui männil, kuid kõrge lubjasisalduse tõttu pidurdab kuuse okasvare loomuldade viljakuse tõusu. Milline puuliik seda soodustab, seile väljaselgitamiseks tuleb analüüsida männi- ja kuusevare lagunemisel tekkivaid huumusaineid. Seejuures tuleb silmas pidada, et kuigi männi osatähtsus mulla ülemiste horisontide mullatekkeprotsesside kiirendamisel on väiksem, ei tohi seda alahinnata. Sügavale paelōhede vahele tungiv männijuurestik intensiivistab pae lagunemist; tekkinud pragudesse aga kuhjub orgaanilist ainet ja areneb mikrobioloogiline tegevus. Järelikult tuleb loomuldade parandamise seisukohast hinnata männi-kuuse segapuistuid. Puuliikide optimaalse vahekorra neis peab välja selgitama edaspidine uurimistöö. 


\section{K I R J A N D US}

B urges, A., 1956. The Release of Cations during the Decomposition of Forest Litter. Trans. 6th Int. Congr. Soill. Sci., vol. B. Paris.

K os e n kranius, H., 1929. Loopealsetest metsadest Saaremaạ läänerannikul. «Eesti Mets», nr. $11 / 12$.

S ch a b a k, E., 1928. Harjumaa pae- ja kaljutüübi rühmadest. «Eesti Mets», nr. 10.

S ch ab a k, E., 1933. Paljasraiestikest. «Eesti Mets», nr. 10.

S e p p, R., 1957. Loomuldade metsakasvatuslikest omadustest. «Looalade metsastamise ja loometsade majandamise küsimusi». Tartu.

А бр а м о в а М. М., 1947. Сезонная изменчивость некоторых химических свойств лесной подзолистой почвы. Тр. Почв. ин-та им. В. В. Докучаева, т. XXV. М.-Л.

3 он н С. В., 1954. Влияние леса на почвы. Изд. АН СССР. М.

К и т ред ж Дж., 1951. Влияние леса на климат, почвы и водный режим. Изд. ИЛ. М.

К о в а лев ск и й А. К., 1953. Залежність кількостівідпаду листя від метеорологічних умов. Питания лісового грунтознавства та екологіі лісу. АН Укр. РСР. Киів.

Мелех ов И. С., 1957. Об отложении лесной подстилки в зависимости от типа леса. Tр. Архангельского лесотехнического ин-та, т. XVII.

Мин а В. Н., 1951. Зольный обмен в дубовых лесах на различных почвах. Тр. ин-та леса АН CCCP, т. VII. M.

М и н а В. Н., 1954. Взаимодействие между древесной растительностью и почвами в некоторых типах дубового леса южной лесостепи. Тр. ин-та леса АН СССР, T. XV. M.

Молч а но в А. А., 1952. Гидрологическая роль сосновых лесов на песчаных почвах. Изд. АН СССР. М.

Р емез ов Н. П., Смирнов а К. М., Быкова Л. Н., 1949. Некоторые итоги изучения роли лесной растительности в почвообразованин. Вестник МГУ, № 6.

Р о д е А. А., 1955. Почвоведение. М.-Л,

С м и рн ов а К. М., 1951а. Круговорот азота и зольных элементов в ельнике-зеленомошнике. Вестник МГУ, № 3 .

С м и рн в а К. M., 195lb. Круговорот азота и зольных элементов в ельниках сложных. Вестник МГУ, № 10.

С те п а нов Н. Н., 1939. Химические свойства лесной подстилки как основного фактора естественного возобновления. Тр. по лесн. опытн, делу Центр. лесн. опытн. ст., вып. II.

С у к а ч е в В. Н., 1947. Основы теории биогеоценологии. Юбилейный сборник, посвященный 30-летию Великой Октябрьской соц. рев., ч. II. М.

Тк а чен к о М. Е., 1952. Общее лесоводство. М.-Л.

Ш у м аков В. С., 1941. Динамика разложения растительных остатков и взаимодействие продуктов их разложения с лесной почвой. Исследования по лесному почвоведению, Труды ВНИИЛХ, т. І, вып. 27.

Eesti NSV Teaduste Akadeemia

Zooloogia ja Botaanika Instituut
Saabus toimetusse

21. IV 1958

\section{КОЛИЧЕСТВО И СОСТАВ ЛЕСНОГО ОПАДА В АЛЬВАРНЫХ ЛЕСАХ}

\section{P. A. Cenn}

\section{Резюме}

Исследование количества годичного опада, его состава и динамики опадения производилось в 1956-1957 гг. на 9 постоянных пробных площадях лесничества Куузику, таксационная характеристика которых приведена в табл. 1. Пробные площади находились на очень маломощных и маломощных перегнойно-карбонатных почвах (рендзинные, или альварные почвы) с мощностью мелкоземистого слоя в 4,4-14,7 см (табл. 2). Степень разложения материнской породы - известняка - была различна. На лучших местах произрастания (пробные площади $1-4$ ) на глубине 30 см соотношение между кусками известняка и мелкозема было 1:10, а массивный неразложившийся известняк находился уже на глубине 20-30 см. На участках с относительно хорошими 
почвенными условиями пронзрастали насаждения III-IV класса бонитета с преобладанием ели. По мере ухудшения почвенных условий участие сосны в насаждениях увеличивается и господствуют насаждения IV-V бонитета. Возраст насаждений на исследованных участках колебался от 51 года до 124 лет.

Исследования показали, что количество опада уменьшается в зависимости от ухудшения почвенных условий, что обусловлено главным образом редкой кроной и охвоением деревьев, растущих на худших местах пронзрастания. Количество воздушносухого опада составляло на более плодородных местах пронзрастания 2400-2600 кг/га и на менее плодородных - 900-1300 кг/га (рис. 1).

В насаждениях с одинаковыми почвенными условиями, но с различным видовым составом, количества годичного опада практически были одинаковы. Незначительное влияние древесных пород на количество опада объясняется тем, что в скудных условиях произрастания альварных лесов крона ели всегда остается редкой. Количество опада, образованного елью, было в 3-4 раза меньше, чем у сосны.

По отдельным составным частям в обшем количестве опада хвои было $50-70 \%$, сухих веток - $13-20 \%$, кусочков коры - 5-10\% и неопределенкого материала (мелкий материал, в котором можно различить небольшие кусочки коры, чешуйки шишек и т. п.) $-6-10 \%$ (табл. 3).

Динамика опадения по отдельным составным частям и временам года различна. Зимой опадало до $40-45 \%$ от общего количества еловой хвои, сухих веток и кусочков коры, а от сосновой хвои - только $10 \%$ (табл. 4).

Поскольку в летние месяцы основную массу опада составляет лучше разлагающаяся сосновая хвоя, то минерализация лесной подстилки происходит быстро. Это является одной из причин, почему в летние месяцы горизонт лесной подстилки в альварных лесах часто отсутствует.

Общее содержание минеральных веществ (\% зольности) в живой еловой хвое равен $3.53 \%$, в сосновой - $1.33 \%$. Отдельных элементов в еловой хвое было (в \% от веса золы): $\mathrm{SiO}_{2}-13,76 ; \mathrm{Fe}_{2} \mathrm{O}_{3}-0,89 ; \mathrm{CaO}-52.29 ; \mathrm{MgO}-4.75 ; \mathrm{MnO}-0,97$ и $\mathrm{P}_{2} \mathrm{O}_{5}-5.08$. $\mathrm{B}$ живой сосновой хвое: $\mathrm{SiO}_{2}-2,76 ; \mathrm{Fe}_{2} \mathrm{O}_{3}-0,89 ; \mathrm{CaO}-24,34 ; \mathrm{MgO}-9,35 ; \mathrm{MnO}-0,78$ н $\mathrm{P}_{2} \mathrm{O}_{5}-16,12 \%$ (табл. 5),

При отмирании хвои пронсходят изменения в ее составе, в связи с чем минеральный состав опада отличается от состава живой хвои. Общее содержание минеральных веществ в опавшей хвое увеличнлось: в еловой хвое \% золы составлял 4.43. и в сосновой хвое - 1.48. В еловой хвое заметно уменьшилось количество $\mathrm{P}_{2} \mathrm{O}_{5}$ и $\mathrm{Fe}_{2} \mathrm{O}_{3}$, a содержание $\mathrm{SiO}_{2}$ несколько увеличилось. В составе живой и опавшей хвои сосны различий больше. Содержание $\mathrm{P}_{2} \mathrm{O}_{5}$ в опаде уменьшилось в 4 раза, а участие всех других элементов увеличилось почти вдвое (табл. 6).

Минеральный состав золы сухих веток и кусочков коры отличается от хвои заметно бо́льшим содержанием $\mathrm{SiO}_{2}$, количество $\mathrm{CaO}$ значительно меньше. Заметное количество $\mathrm{Fe}_{2} \mathrm{O}_{3}$ и $\mathrm{P}_{2} \mathrm{O}_{5}$, превышающее содержание таковых в опавшей хвое, имеется в золе сухих веток.

При выяснении интенсивности круговорота минеральных веществ имеет значение их количество в воздушно-сухом веществе (табл. 7). $\mathrm{SiO}_{2}$ возвращается в наибольшей степени кусочками коры; ветками и.еловой хвоей - наполовину меньше, а сосновой хвоей - в 10 раз меньше. $\mathrm{Fe}_{2} \mathrm{O}_{3}$ в опавших на землю ветках и кусочках коры более пем в 2 раза меньше, чем в хвое. Известью обогащают почву более всего еловая хвоя и кусочки коры. В сосновой хвое и ветках $\mathrm{CaO}$ содержится в одинаковом количестве, но наполовину меньше, чем в еловой хвое. Магнезии в хвое в 3 раза больше, чем в ветках и кусочках коры. По содержанию $\mathrm{MnO}$ на первом месте стоит еловая хвоя, в остальном материале ее значительно меньше. Фосфора более всего на поверхность земли попадает с еловой хвоей и ветками.

Общее количество возвращаемых минеральных веществ колеблется на исследованных участках в больших пределах - от $70 \mathrm{kr} /$ га на относительно пронзводительных местах произрастания до $20 \mathrm{kr} /$ га на худших (рис. 7). Более всего возвращается СаO; $\mathrm{SiO}_{2}$ - почти в 3 раза меньше. Другие элементы возвращаются в значительно меньших количествах, и их можно расположить по нисходящей степени следующим образом: $\mathrm{MgO}-\mathrm{P}_{2} \mathrm{O}_{5}-\mathrm{MnO}$ (табл. 8). 


\section{DIE MENGE UND ZUSAMMENSETZUNG DES WALDABFALLES IM ALVARENWALD}

\section{R. Sepp}

\section{Zusammenfassung}

Untersuchungen über die Menge und Zusammensetzung des jährlichen Waldabialles, sowie über die Dynamik des Fallens wurden in den Jahren 1956-1957 auf neun ständigen Probeflächen der Forstei Kuusiku (siehe deren Bestandesbeschreibung in Tabelle 1) durchgeführt.

Die Probeflächen befanden sich auf dünnen und sehr dünnen Humuskarbonatböden (Rendzina- oder Alvarenböden), wo die feinerdige Bodenschicht $4,4-14,7 \mathrm{~cm}$ mächtig ist (Tabelle 2).

Der Zersetzungsgrad des Untergrundes (Kalkstein) war verschieden. Auf den besseren Standorten (die Probeflächen Nr. 1-4) war das Verhältnis zwischen Kalkstein-

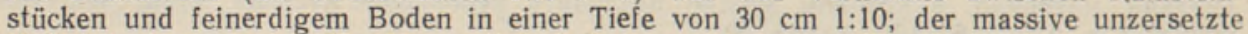
Kalkstein befand sich 50-60 $\mathrm{cm}$ tief. Auf den schlechteren Standorten befand sich der massive Kalkstein schon $20-30 \mathrm{~cm}$ tief.

Auf den besseren Standorten wuchsen Bestände der III und IV Bonitätsklasse, vornehmlich Fichten.

Mit der Verschlechterung der Bodenbedingungen nahm der Anteil der Kiefer zu und wurden Bestände der IV und V Bonitätsklasse vorherrschend. Das Alter der Bestände schwankte auf den untersuchten Flächen zwischen 51 und 124 Jahren.

Die Untersuchungen zeigten, dass die Menge des Waldabfalles sich mit der Verschlechterung der Bodenbedingungen vermindert, was hauptsächlich den weniger dichten Kronen und der dürftigeren Benadelung der auf den schlechteren Standorten wachsenden Bäume geschuldet ist.

Die Menge des lufttrockenen Abfalles war auf den besseren Standorten 2400$2600 \mathrm{~kg} / \mathrm{ha}$, auf den schlechteren $900-1300 \mathrm{~kg} / \mathrm{ha}$ (Abb. 1).

In Beständen mit gleichartigen Bodenbedingungen, doch mit verschiedener Zusammensetzung der Holzarten waren die jährlichen Mengen des Waldabfalles praktisch gleich. Die wenig merkliche Wirkung der Holzarten auf die Menge des Waldabfalles ist dadurch zu erklären, dass in den ungünstigen Wachstumsbedingungen der Alvarenwälder die Fichtenkrone immer undicht bleibt. Die von der Fichte gebildete Menge des Waldabfalles war 3-4-mal kleiner als bei der Kiefer.

Den einzelnen Komponenten nach bestand die Gesamtmenge des Waldabfalles zu 50-70\% aus Nadeln, zu $13-20 \%$ aus dürrem Geäst, zu $5-10 \%$ aus Rindestücken und zu 6-10\% aus Mischmaterial (feines schuttartiges Material), worin kleinere Rindestücke, Zapfenschuppen und dgl. zu unterscheiden sind (Tabelle 3).

Die Dynamik der Bildung des Waldabfalles ist je nach den einzelnen Komponenten und Jahreszeiten verschieden. Im Winter fiel bei der Fichte $40-45 \%$ von der Gesamtmenge der Nadeln, trockenen Zweige und Rindestücke, bei der Kiefer aber bloss $10 \%$ (Tabelle 4).

$\mathrm{Da}$ in den Sommermonaten die sich besser zersetzenden Kiefernnadeln die Hauptmasse des Waldabfalles bilden, erfolgt die Mineralisierung der Waldstreu rasch. Es ist dies auch eine Ursache, warum in den Sommermonaten der Waldstreuhorizont in den Alvarenwäldern oft fehlt.

- Die Gesamtmenge der Mineralstoffe (der Aschengehalt) war in den frischen Fichtennadeln $3,53 \%$, in den Kiefernnadeln $1,33 \%$. Die Menge der einzelnen Elemente war in den Fichtennadeln (in \% vom Aschengewicht): $\mathrm{SiO}_{2}-13,76, \mathrm{Fe}_{2} \mathrm{O}_{3}-0,89$, $\mathrm{CaO}-52,29, \mathrm{MgO}-4,75, \mathrm{MnO}-0,97$ und $\mathrm{P}_{2} \mathrm{O}_{5}-5,08$. In den frischen Kiefernnadeln: $\mathrm{SiO}_{2}-2,76, \mathrm{Fe}_{2} \mathrm{O}_{3}-0,89, \mathrm{CaO}-24,34, \mathrm{MgO}-9,35, \mathrm{MnO}-0,78$ und $\mathrm{P}_{2} \mathrm{O}_{5}-$ 16,12 (Tabelle 5).

Beim Absterben der Nadeln erfolgen in ihrer Zusammensetzung gewisse Veränderungen, weswegen die mineralische Zusammensetzung des Waldabfalles sich von der Zusammensetzung der lebendigen Nadeln unterscheidet. Die Gesamtmenge der Mineralstoffe in den Nadeln des Waldabfalles nimmt zu: der Aschengehalt der Fichtennadeln ist jetzt $4,43 \%$, der Kiefernnadeln $1,48 \%$. Der Gehalt an $\mathrm{P}_{2} \mathrm{O}_{5}$ und $\mathrm{Fe}_{2} \mathrm{O}_{3}$ wird in den Fichtennadeln merklich geringer, der Anteil des $\mathrm{SiO}_{2}$ nimmt einigermassen zu. Bei der Kiefer sind die Verschiedenheiten in der Zusammensetzung der lebendigen Nadeln und der Nadeln des Waldabfalles noch viel grösser. Der Phosphorgehalt wird im Waldabfalle 4-mal geringer, der Anteil der anderen Elemente verdoppelt sich nahezu (Tabelle 6).

Die mineralische Zusammensetzung der Asche der trockenen Zweige und Rindestücke unterscheidet sich merklich von der der Nadeln: der Gehalt an $\mathrm{SiO}_{2}$ ist merklich 
grösser, der $\mathrm{CaO}$-gehalt bedeutend kleiner. Beachtenswert ist der grosse $\mathrm{Fe}_{2} \mathrm{O}_{3}$ - und $\mathrm{P}_{2} \mathrm{O}_{5}$-gehalt in der Asche der trockenen Zweige, der den entsprechenden Gehalt in den Nadeln des Waldabfalles übertrifft. Bei der Beurteilung der Menge der von den Bestandteilen des Waldabfalles dem Boden zurückgegebenen Mineralstoffe ist ihre Menge im lufttrockenen Stoff wichtig (Tabelle 7). $\mathrm{SiO}_{2}$ wird am meisten in Rindestücken zurückgegeben; in Zweigen und Fichtennadeln um die Hälfte weniger, in Kiefernnadeln zehnmal weniger. Zweige und Rindestücke, die zu Boden fallen, enthalten 2-mal weniger $\mathrm{Fe}_{2} \mathrm{O}_{3}$ als Nadeln. Kalk geben dem Boden besonders die Fichtennadeln und Rindestücke. Der $\mathrm{CaO}$-gehalt in den Zweigen und Kiefernnadeln ist der gleiche und bildet die Hälite des CaO-gehalts der Fichtennadeln. Der Magnesiumgehalt der Nadeln ist 3-mal grösser, als der der Zweige und Rindestücke. Der MnO-gehalt ist am grössten in den Fichtennadeln; in den anderen Bestandteilen des Waldabfalles ist er merklich kleiner. Der meiste Phosphor wird dem Boden mit den Zweigen und Fichtennadeln zurückgegeben.

Die Gesamtmenge der jährlich dem Boden zurückgegebenen Mineralstoffe war auf den untersuchten Flächen schwankend: auf den besseren Standorten betrug sie $70 \mathrm{~kg} / \mathrm{ha}$, auf den schlechteren $20 \mathrm{~kg} / \mathrm{ha}$ (Abb. 7).

$\mathrm{Am}$ meisten wird $\mathrm{CaO}$ zurückgegeben; $\mathrm{SiO}_{2}$ aber fast dreimal weniger. Andere Elemente werden in merklich kleineren Mengen zurückgegeben; wenn man sie nach der fallenden Menge der zurückgegebenen Stoffs ordnet, so ergeben sie die folgende Reihe: $\mathrm{MgO}-\mathrm{P}_{2} \mathrm{O}_{5}-\mathrm{F}_{2} \mathrm{O}_{3}-\mathrm{MnO}$ (Tabelle 8).

Institut für Zoologie und Botanik der Akademie der Wissenschaften der Estnischen SSR
Eingegangen

am 21. April 1958 